\title{
Uji Efektivitas Daya Hambat Ekstrak Etil Asetat Kulit Batang Kamboja (Plumeria acuminata, Ait.) Terhadap Jamur Fusarium oxysporum fsp. cepae
}

Ni Luh Putu Nina Sriwarthini ${ }^{1}$, Dwi Soelistya Dyah Jekti ${ }^{2}$, Prapti Sedijani ${ }^{2}$

${ }^{1}$ Mahasiswa Program Studi Magister Pendidikan IPA Program Pasca Sarjana Universitas Mataram

${ }^{2}$ Dosen Program Studi Magister Pendidikan IPA Program Pasca Sarjana Universitas Mataram nina.sriwarthini@gmail.com

\begin{abstract}
Abstrak
Penelitian yang dilakukan ini dilakukan untuk menganalisis: konsentrasi ekstrak etil asetat kulit batang tanaman kamboja yang paling efektif dalam menghambat pertumbuhan jamur Fusarium oxysporum fsp. cepae. Penelitian ini merupakan penelitian eksploratif eksperimen. Metode pengujian sampel yang digunakan yaitu metode uji sensitivitas. Rancangan yang digunakan adalah Rancangan Acak Lengkap (RAL). Data uji daya hambat dianalisis dengan mengukur diameter zona hambat bakteri uji dan dianalisis menggunakan ANOVA (Analysis Of Varians) yang dilanjutkan dengan uji beda nyata terkecil (BNT). Hasil penelitian menunjukkan bahwa seluruh konsentrasi ekstrak etil asetat mulai dari 5, 20, 35, 50 dan 65\% efektif menghambat pertumbuhan jamur patogen dan membentuk zona hambat yang termasuk dalam kategori sangat kuat.
\end{abstract}

Kata kunci: Kulit batang, Kamboja, daya hambat, Fusarium.

\begin{abstract}
The aim of this research was to analyze : The most effective concentration that could inhibit the growth of Fusarium oxysporum $f_{s p}$. cepae. This was an explorative experimental research. Samples are examined by sensitivity test. Design of this research was Complete Random Design. Data were collected by measuring the clear zone diameter of fungu's growth inhibition and analyzed using Analysis Of Varians (ANOVA) then continued by using LSD (Least Significance Difference) test. The result showed that all the concentration of ethyl acetate extract start from 5 , $20,35,50$ and $65 \%$ effective inhibit the growth of patogen fungi and produced clear zone in very strong categories.
\end{abstract}

Keywords: Bark, Plumeria acuminata, inhibition potention, Fusarium 


\section{PENDAHULUAN}

Tanaman kamboja (Plumeria acuminata, Ait.) sejak dulu banyak digunakan sebagai obat tradisional, mulai dari kulit batang, getah, akar, bunga maupun daunnya dimanfaatkan untuk mengobati kaki pecah-pecah, obat sakit gigi, pencahar, mencegah nanah pada luka, mengurangi pembengkakan, bahkan sebagai obat diabetes. Kamboja mudah dicari dan mudah pula diproses menjadi obat. Senyawa aktif fulvoplumierin, flavonoid, alkaloid, polifenol, yang terkandung dalam tumbuhan ini memperlihatkan daya hambat terhadap pertumbuhan bakteri maupun jamur (Choudhary et al., 2014). Beberapa penelitian terkait mengenai khasiat tanaman kamboja yaitu; penelitian Widodo et al. (2010), yang menunjukkan bahwa, ekstrak etil asetat daun kamboja dapat menyembuhkan infeksi Staphylococcus aureus pada punggung kelinci paling cepat dibandingkan dengan ekstrak etanol. Fraksi etil asetat pada konsentrasi 15\% mampu menyembuhkan infeksi selama 11,40 hari, konsentrasi 20\% mampu menyembuhkan infeksi selama 10,60 hari, konsentrasi 25\% mampu menyembuhkan infeksi selama 9,40 hari. Selain daunnya, bunga kamboja juga mengandung zat yang bersifat antibakteri. Santoso et al., (2010), dalam penelitiannya memperoleh kadar bunuh minimal (KBM) ekstrak bunga kamboja terhadap Shigella dysentriae pada konsentrasi 35\%. Getah kamboja (Plumeria acuminata, Ait) diketahui juga dapat dimanfaatkan sebagai antiseptik. Hasil penelitian

Sebagian besar patogen penyebab penyakit tumbuhan berupa jamur, bakteri, virus, mikoplasma, alga, protozoa, dan nematoda. Jamur Fusarium oxysporum fsp. cepae adalah salah satu jenis jamur patogen yang mematikan, karena patogen ini mempunyai strain yang dapat dorman selama 30 (tiga puluh) tahun sebelum melanjutkan virulensi dan menginfeksi tanaman.
Jamur ini dapat menyebar melalui pengangkutan bibit dan tanah yang terbawa angin, air atau alat pertanian. Populasi patogen dapat bertahan secara alami di dalam tanah dan pada akar-akar tanaman sakit. Selama ini pengendalian penyakit tanaman sebagian besar menggunakan pestisida sintetik. Penggunaan pestisida sintetik yang tidak bijaksana akan merusak lingkungan dan kesehatan manusia (Suryaningsih dan Hadisoeganda, 2004).

Sehingga sangat perlu dilakukan penelitian untuk mengetahui efektivitas ekstrak etil asetat kulit batang kamboja untuk menghambat pertumbuhan jamur Fusarium oxysporum $f_{s p}$. cepae, sebagai alternatif agen pengendali organisme pengganggu tanaman alami.

\section{BAHAN DAN METODE}

Penelitian ini merupakan penelitian eksploratif eksperimen, dengan menggunakan rancangan percobaan acak lengkap (RAL). Penelitian ini dilakukan di Laboratorium Mikrobiologi FKIP, Laboratorium Kimia FKIP dan Laboratorium Mikrobiologi dan Bioteknologi Pertanian Universitas Mataram dari bulan Desember 2016 - Mei 2017. Adapun variabel bebas dalam penelitian ini yaitu ekstrak etil asetat kulit batang tanaman kamboja dan jamur endofit yang diisolasi dari kulit batang tanaman kamboja. Sedangkan variabel terikat dalam penelitian ini yaitu efektivitas ekstrak etil asetat kulit batang tanaman kamboja dan jamur endofit dalam menghambat pertumbuhan jamur Fusarium oxysporum fsp. cepae. Populasi dalam penelitian ini adalah tanaman kamboja. Sampel penelitiannya adalah kulit batang tanaman kamboja dan jamur endofit yang diisolasi dari kulit batang tanaman kamboja. Adapun kontrol negatif yang digunakan yaitu aquadest dan kontrol positif yang digunakan yaitu etil asetat (PA) dan alkohol Teknis 70\%. 
Bahan - bahan yang digunakan dalam penelitian ini yaitu, kulit batang tanaman kamboja, aquadest, media Potato Dextrose Agar, media Saboraud Dextrose Agar, kertas saring, Isolat jamur $F$. oxysporum fsp. cepae, $\mathrm{BaCl}_{2}, \mathrm{H}_{2} \mathrm{SO}_{4}$, kertas label, sendok, lidi, kapas, kertas jagung, etil asetat, alkohol $70 \%$, tissue, garam fisiologis, pewarna Lacto cotton blue, simplisia kulit batang kamboja, korek api, spiritus, streptomycin, dan sodium hypoclorite $5 \%$.

Pelaksanaan penelitian ini dimulai dari isolasi jamur Fusarium oxysporum fsp. cepae dari bawang merah, pembuatan ekstrak dengan teknik maserasi, evaporasi dengan rotary evaporator, dan pengenceran ekstrak kedalam 5 variasi yaitu 5, 20, 35, 50 dan $60 \%$.

Larutan pengencer yang digunakan adalah aquadest. Pengenceran dilakukan dengan cara melarutkan sejumlah ekstrak kulit batang kamboja dari hasil evaporasi ke dalam pelarut yang telah ditentukan. Agar ekstrak dan pelarut dapat tercampur ditambahkan $0,5 \mathrm{ml}$ larutan tween 80. Konsentrasi larutan ekstrak yang digunakan adalah konsentrasi dalam persen berat pervolume $(\mathrm{w} / \mathrm{v})$, dengan konsentrasi $5 \%$ (gr ekstrak/ml pelarut), 20\% (gr ekstrak/ml pelarut) $35 \%$ (gr ekstrak $/ \mathrm{ml}$ pelarut), 50\% (gr ekstrak $/ \mathrm{ml}$ pelarut), dan $65 \%$ (gr ekstrak/ml pelarut) (Santoso et al., 2010).

Uji efekitivitas bakteri ekstrak etil asetat kulit batang kamboja terhadap jamur Fusarium oxysporum $f_{s p}$. cepae menggunakan metode difusi sumuran. Suspensi jamur Fusarium fsp. cepae dengan jumlah $3 \times 10^{8} \quad \mathrm{CFU} / \mathrm{ml}$ diusapkan secara merata pada 5 plate media SDA menggunakan kapas swab yang steril, kemudian didiamkan selama 10 menit dalam inkubator agar suspensi jamur meresap pada media kultur. Pembuatan sumuran dilakukan dengan cara membuat 1 lubang dengan diameter $6 \mathrm{~mm}$ pada agar padat yang telah diinokulasikan dengan jamur Fusarium oxysporum fsp. cepae. Masing-masing lubang tersebut kemudian diinjeksikan ekstrak kulit batang kamboja dalam 5 variasi konsentrasi yang akan diuji. Jumlah ekstrak yang diinjeksikan pada masingmasing sumuran pada setiap plate yaitu $100 \mu \mathrm{l}$. Kemampuan daya respon hambatan pertumbuhan fungi menurut Puthera et al., dalam Alfiah et al., (2015) adalah $<10 \mathrm{~mm}$ lemah, 10-15 mm sedang, 16-20 mm kuat, dan > $20 \mathrm{~mm}$ sangat kuat. Data diameter daya hambat yang terbentuk kemudian dianalisis secara kuantitatif dengan uji Anova menggunakan program Statistical Product and Service Solutions (SPSS) 20. Perlakuan yang berpengaruh nyata atau sangat nyata diuji lanjut dengan uji lanjut BNT dengan taraf $\alpha=0,05$.

\section{HASIL DAN PEMBAHASAN}

Tabel 1. Zona Hambat Ekstrak Etil Asetat Kulit Batang Tanaman Kamboja Terhadap Jamur Fusarium oxysporum fsp. cepae.

\begin{tabular}{lccccc}
\hline $\begin{array}{l}\text { Jamur } \\
\begin{array}{l}\text { Fusarium } \\
\text { oxysporum } \\
\text { fsp. cepae }\end{array}\end{array}$ & \multicolumn{5}{c}{$\begin{array}{c}\text { Konsentrasi ekstrak etil asetat kulit batang } \\
\text { tanaman kamboja }\end{array}$} \\
\cline { 2 - 6 } & $\mathbf{5 \%}$ & $\mathbf{2 0 \%}$ & $\mathbf{3 5 \%}$ & $\mathbf{5 0 \%}$ & $\mathbf{6 5 \%}$ \\
\hline Ulangan 1 & 35 & 40 & 54 & 61 & 79 \\
\hline Ulangan 2 & 39 & 42 & 53 & 60 & 75 \\
\hline Ulangan 3 & 38 & 43 & 50 & 59 & 70 \\
\hline Rata - rata & 37,3 & 41,6 & 52,3 & 60 & 74,6 \\
\hline Kategori & SK & SK & SK & SK & SK \\
\hline Keterangan & & & &
\end{tabular}

Keterangan :

L : Lemah

SK : Sangat Kuat

S : Sedang (Puthera et al., dalam Alfiah, 2015). 


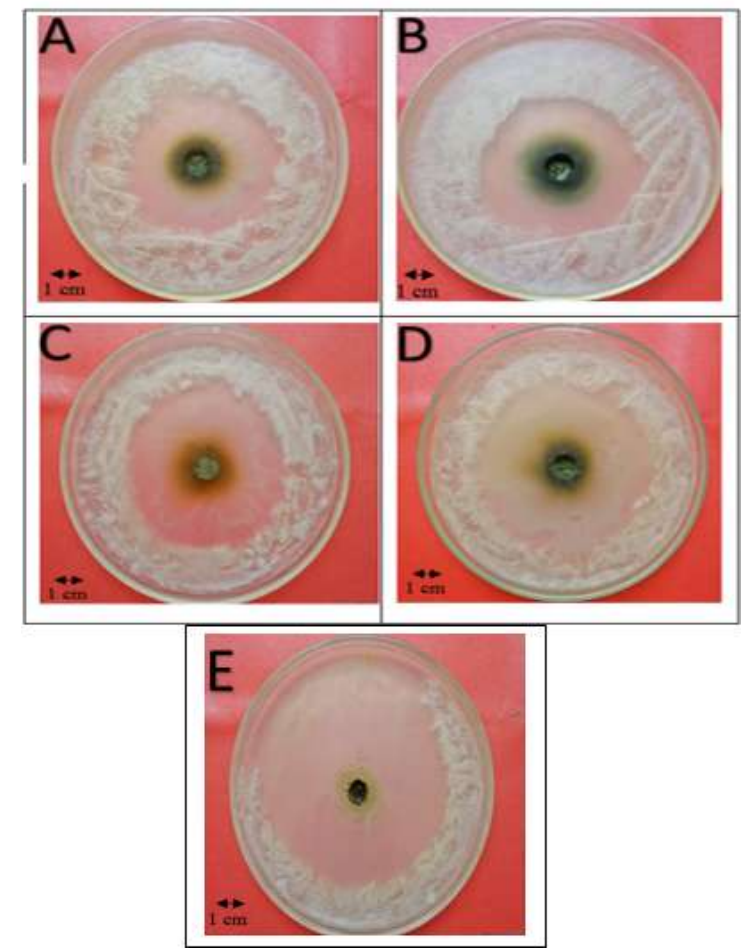

Gambar 1. Daya hambat ekstrak etil asetat kulit batang tanaman kamboja dalam berbagai konsentrasi. (A) Konsentrasi 5\%; (B) Konsentrasi 20\%; (C) Konsentrasi 35\%; (D) Konsentrasi 50\%; $€$ Konsentrasi $65 \%$.

Hasil penelitian yang dilakukan menunjukkan bahwa ekstrak etil asetat kulit batang tanaman kamboja secara keseluruhan dapat menghambat pertumbuhan jamur patogen Fusarium oxysporum fsp. cepae. Konsentrasi 5, $20,35,50 \%$ dan $65 \%$ seluruhnya menunjukkan zona hambat dengan kategori sangat kuat menurut Puthera et al., dalam Alfiah, 2015). Konsentrasi 5\% menghasilkan rata - rata zona hambat sebesar $37,3 \mathrm{~mm}$, konsentrasi $20 \%$ menghasilkan zona hambat sebesar 41,6 mm, konsentrasi $35 \%$ menghasilkan zona hambat sebesar 52,3 mm, konsentrasi $50 \%$ menghasilkan zona hambat sebesar $60 \mathrm{~mm}$, dan konsentrasi $65 \%$ menghasilkan zona hambat sebesar 74,6 $\mathrm{mm}$. Zona hambat yang tergolong kedalam kategori sangat kuat bahkan pada konsentrasi terkecil ini diduga karena berbagai senyawa yang terkandung dalam kulit batang tanaman kamboja yang bersifat antifungi seperti senyawa flavonoid, polifenol, dan saponin. Senyawa flavanoid umumnya bersifat antioksidan dan telah digunakan sebagai salah satu komponen bahan baku obat-obatan. Senyawa flavanoid dan turunanya memilki dua fungsi fisiologi tertentu, yaitu sebagai bahan kimia untuk mengatasi serangan penyakit (sebagai antibakteri dan antifungi) dan anti virus bagi tanaman. Flavonoid dapat berikatan dengan dinding sel melalui sebuah kompleks proteinfenol, yang melibatkan adanya ikatan hidrogen antara protein dan fenol. Kompleks ini nantinya akan dapat menyebabkan kerusakan (denaturasi) ikatan hidrogen dalam protein pada dinding sel jamur. Selanjutnya, kerusakan inilah yang membuat matriks intraseluler jamur keluar sehingga akhirnya menyebabkan kematian sel jamur. Selain itu, senyawa flavonoid juga mampu menghambat pertumbuhan spora jamur (Cushnie dan Lamb, 2005).

Senyawa polifenol pada konsentrasi rendah dapat merusak membran sitoplasma, sedangkan pada konsentrasi tinggi senyawa fenol ini berkoagulasi dengan protein seluler. Mekanisme kerja tanin menciutkan dan mengendapkan protein dengan membentuk senyawa yang tidak larut. Saponin dapat memecahkan lemak pada membran sel sehingga menyebabkan gangguan permeabilitas membran sel. Hal tersebut mengakibatkan proses difusi bahan atau zat-zat yang diperlukan oleh jamur dapat terganggu, akibatnya sel jamur dapat mengembang hingga pecah Putri et al., (2014).

Tabel 2. Analisis Of Varians (ANOVA) ekstrak etil asetat Kulit Batang Tanaman Kamboja Terhadap Jamur Fusarium oxysporum fsp. cepae.

\begin{tabular}{llllcrc}
\hline $\begin{array}{l}\text { Sumber } \\
\text { Variasi }\end{array}$ & $\begin{array}{l}\text { Jumlah } \\
\text { Kuadrat }\end{array}$ & $\begin{array}{l}\text { Derajat } \\
\text { Kebebasan }\end{array}$ & $\begin{array}{l}\text { Kuadrat } \\
\text { Tengah }\end{array}$ & F Hit. & \multicolumn{2}{c}{ Ftabel } \\
\hline $\begin{array}{l}\text { Antar } \\
\text { Kelompok }\end{array}$ & 2677.733 & 4 & 669.443 & 103.521 & 3.47805 & 5.99433 \\
$\begin{array}{l}\text { Dalam } \\
\text { Kelompok }\end{array}$ & 64.667 & 10 & 6.467 & & & \\
Total & 2742.400 & 14 & & & & \\
\hline
\end{tabular}

Tabel diatas menunjukkan bahwa, ekstrak kulit batang kamboja (Plumeria acuminata, Ait.) dalam berbagai variasi ternyata berbeda nyata 
karena diperoleh F hitung sebesar 103,521 sedangkan $F$ tabel dengan signifikansi 0,01 sebesar 5,99433 dan $\mathrm{F}$ tabel dengan signifikansi 0,05 sebesar 3,47805 (F hitung > F tabel), selanjutnya dilakukan uji lanjut BNT (LSD).

Tabel 3. Uji Beda Nyata Terkecil (BNT) ekstrak etil asetat Kulit Batang Tanaman Kamboja Terhadap Jamur Fusarium oxysporum fsp. cepae.

\begin{tabular}{lllc}
\hline Perlakuan & $\begin{array}{c}\text { Rata }- \\
\text { Rata }\end{array}$ & $\begin{array}{c}\text { Rata }- \text { rata } \\
+ \text { BNT }\end{array}$ & Nilai $B N T_{0,05}$ \\
\hline Konsentrasi 5\% & 37,33 & $43.25418^{a}$ & 5.924176 \\
& & & \\
Konsentrasi 20\% & 41,66 & $47.58418^{b}$ & 5.924176 \\
Konsentrasi 35\% & 52,33 & $58.25418^{c}$ & 5.924176 \\
Konsentrasi 50\% & 60 & $65.92418^{d}$ & 5.924176 \\
Konsentrasi 65\% & 74,66 & $80.58418^{e}$ & 5.924176 \\
\hline
\end{tabular}

Keterangan : angka-angka yang diikuti huruf yang sama pada kolom yang berbeda berarti tidak menunjukkan perbedaan yang nyata berdasarkan uji BNT pada taraf $5 \%$.

Hasil analisis varians (ANOVA) yang dilakukan memperoleh nilai $\mathrm{F}$ hitung yang lebih besar dari F Tabel pada masing - masing konsentrasi ekstrak, sehingga kemudian dilakukan uji lanjut BNT (Beda Nyata Terkecil) untuk mengetahui perbedaan masing - masing konsentrasi berdasarkan nilai rata-rata tiap perlakuan. Hasil uji BNT menunjukkan bahwa nilai rata - rata tiap konsentrasi berbeda nyata. Hasil penelitian menunjukkan bahwa, ekstrak kulit batang tanaman kamboja memiliki potensi antifungi terhadap jamur patogen Fusarium oxysporum fsp. cepae. Terbukti dengan besarnya diameter zona hambat yang terbentuk melebihi kontrol positif (alkohol dan etil asetat) yang hanya sebesar $27 \mathrm{~mm}$ (Alkohol) dan $17 \mathrm{~mm}$ (Etil asetat). Ini diduga akibat senyawa aktif yang terdapat pada ekstrak etil asetat kulit batang tanaman kamboja seperti flavonoid, polifenol, dan saponin yang efektif menganggu dan menghambat aktivitas metabolisme jamur patogen, namun perlu dilakukan uji lapangan untuk mempertegas hasil uji invitro di laboratorium agar ekstrak maupun kulit batang tanaman kamboja dapat digunakan sebagai pengendali hayati/ biofungisida alami.

\section{KESIMPULAN}

Berdasarkan hasil penelitian dan analisis data dapat disimpulkan bahwa seluruh konsentrasi ekstrak etil asetat kulit batang tanaman kamboja efektif dalam menghambat pertumbuhan jamur Fusarium oxysporum $f_{s p}$. cepae dan tergolong kedalam kategori sangat kuat menurut Puthera et al., dalam Alfiah, 2015.

\section{DAFTAR PUSTAKA}

Alfiah, R. R., Khotimah, S. dan Turnip, M. 2015. Efektivitas Ekstrak Metanol Daun Sembung Rambat (Mikania micrantha Kunth) Terhadap Pertumbuhan Jamur Candida albicans. Jurnal Protobiont. Vol. 4. No. 1. Hal 53.

Arnold, A.E., 2000. Fungal Endophytes of Tropical Trees : Methods and Potential for Biological Control of Fungal Pathogen of Cocoa. Tuscon USA: Department of Ecology and Evolutionary Biology, University of Arizona.

Barnett, .L. 1955. Illustrated genera of imperfect fungi.Minneapolis: Burgess Publishing Co.

Barnett, H. L., Barry Hunter, B. 1998. Illustrated genera of imperfect fungi, fourth edition. St. Paul, Minnesota: APS Press.

Choudhary M., Kumar V. and Singh S. 2014. Phytochemical and Pharmacological activity of Genus Plumeria: An updated review. International Journal of Biomedical And Advance Research: 266-271.

Cushnie T.P., Lamb A.J. 2005. Antimicrobial Activity Of Flavonoid. Int. J. Antimicrobial Agents. : 26345 - 5.

Putri, R. H., Barrid, I., Kusumawardani, B. 2014. Daya Hambat Ekstrak Tembakau Terhadap Pertumbuhan Mikroba Rongga Mulut. Stomatognatik (Jurnal Kedokteran Gigi Universitas Jember) Vol. 11 no 2. 27-31 
Santoso, T., Noorhamdani, Sidharta, Bambang. 2010. Uji Ekstrak Bunga Kamboja (Plumeria acuminatae, Ait) Sebagai Antimikroba Terhadap Shigella dysenteriae Secara In Vitro. Jurnal Kedokteran Universitas Brawijaya.

Suryaningsih, E. dan W. Hadisoeganda. 2004. Pestisida Botani untuk Mengendalikan Hama dan Penyakit pada Tanaman Sayuran. Bandung : Mitra Buana Pasundan.
Widodo, G. P., Ningsih, D., Aprilia, M . 2010. Aktivitas Antibakteri dan Penyembuhan Luka Fraksi-Fraksi Ekstrak Etanol dan Etil Asetat Daun Kamboja (Plumeria acuminate, Ait) pada Kulit Kelinci yang Diinfeksi Staphylococcus aureus. Jurnal Farmasi Indonesia. 